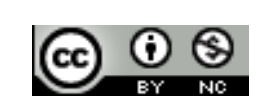

\title{
Pengembangan Buku Pengayaan \\ Keterampilan Menulis Permulaan yang Bermuatan Nilai Karakter pada Peserta Didik Kelas I SD
}

\author{
Eka Yulin Andriani $^{1)}$, Subyantoro ${ }^{2)}$, Hari Bakti Mardikantoro ${ }^{3)}$ \\ 1. Pendidikan Bahasa Indonesia, Program Pascasarjana, Universitas Negeri Semarang \\ E-mail: aekayulin@yahoo.com \\ 2. Universitas Negeri Semarang \\ E-mail: bintoro@mail.unnes.ac.id \\ 3. Universitas Negeri Semarang \\ E-mail: haribaktim@mail.unnes.ac
}

\begin{abstract}
Abstrak: Tujuan penelitian ini adalah (1) mendeskripsikan karakteristik kebutuhan buku pengayaan keterampilan menulis permulaan yang bermuatan nilai karakter pada peserta didik kelas I sekolah dasar, (2) merumuskan prinsip-prinsip penyusunan buku pengayaan keterampilan menulis permulaan yang bermuatan nilai karakter pada peserta didik kelas I sekolah dasar, (3) menyusun prototipe buku pengayaan keterampilan menulis permulaan yang bermuatan nilai karakter pada peserta didik kelas I sekolah dasar, (4) menguji keefektifan buku pengayaan keterampilan menulis permulaan yang bermuatan nilai karakter pada peserta didik kelas I sekolah dasar. Desain penelitian ini adalah pendekatan R\&D (Reseach and Development) dengan langkah penelitian yaitu (1) analisis teoretis dan praktis; (2) analisis kebutuhan peserta didik dan guru; (3) penyususnan prototipe; (4) uji prototipe kepada ahli dan guru; (5) revisi prototipe; (6) uji coba lapangan; dan (7) deskripsi hasil penelitian. Data dalam penelitian ini meliputi data kebutuhan pengembangan buku pengayaan menurut peserta didik dan persepsi guru, data hasil penilaian ahli, dan data uji coba terbatas berupa skor. Sampel penelitian ini adalah sumber belajar menulis permulaan pada kelas I SD. Hasil Penelitian adalah (1) karakteristik kebutuhan buku pengayaan pada peserta didik SD kelas I berdasarkan minat peserta didik dan persepsi guru, (2) perumusan prinsip-prinsip penyusunan buku pengayaan keterampilan menulis permulaan yang bermuatan nilai karakter, (3) pengembangan prototipe untuk peserta didik SD kelas I dengan menggunakan teknik 5M (mengeblat, menghubungkan, menatap, melengkapi, menyalin), (4) validitas dan reliabilitas prototipe buku pengayaan keterampilan menulis permulaan yang bermuatan nilai karakter pada peserta didik kelas I SD.
\end{abstract}

Kata Kunci: buku pengayaan,; menulis permulaan; teknik 5M (mengeblat, menghubungkan, menatap, melengkapi, menyalin).

\section{PENDAHULUAN}

Buku pengayaan memiliki peran penting dalam kegiatan belajar mengajar. Bagi peserta didik, buku pengayaan yang digunakan menyajikan soal latihan lebih banyak dan bervariasi. Dengan demikian, peserta didik akan lebih terbantu untuk memahami materi yang diajarkan guru. Terlebih dalam keterampilan berbahasa, semakin banyak peserta didik berlatih, maka semakin terasah pula keterampilan yang dimilikinya. Selain itu, buku pengayaan juga memiliki peran penting bagi guru karena keterbatasan materi dan contoh latihan soal di buku teks, guru terbantu oleh buku pengayaan yang lebih fokus pada satu materi pembelajaran untuk diajarkan pada peserta didik sebagai buku pendamping sehingga tidak ada alasan bagi guru untuk tidak memberikan variasi soal latihan pada peserta didik.

Buku pengayaan memiliki fungsi sebagai buku pelajaran pelengkap. Sebagaimana dipaparkan oleh Suroso (2007:112) tentang jenis buku pendidikan, yaitu: (1) buku pelajaran pokok yang digunakan dalam kegiatan belajar mengajar yang memuat bahan pelajaran seperti tercantum dalam kurikulum yang berlaku, dipilih dan disusun secara teratur dan harus dikuasai oleh siswa pada jenis dan tingkat pendidikan tertentu serta harus direkomendasikan oleh pemerintah yaitu Pusat Perbukuan Nasional; (2) buku pelajaran pelengkap merupakan buku yang berisi pengayaan dan sebagian pokok bahasan pada mata pelajaran tertentu, 
disusun secara bersistem, mendukung pelaksanaan kurikulum
dan digunakan dalam kegiatan belajar mengajar sebagai pelengakap materi buku pelajaran pokok; (3) buku bacaan digunakan untuk memperkaya pengetahuan dan memperluas wawasan peserta didik untuk membentuk watak, kepribadian, sikap, megembangkan keterampilan, dan memberi hiburan dan buku bacaan dapat dibagi menjadi buku bacaan fiksi dan nonfiksi; dan (4) buku sumber yaitu buku yang digunakan sebagai sumber rujukan untuk memperoleh informasi yang diperlukan dalam memperluas dan memperkaya ilmu pengetahuan. Dengan demikian, buku pengayaan sebagai buku pelengkap pembelajaran, memiliki fungsi untuk mendampingi buku teks, dengan tujuan untuk menambah pengetahuan dan wawasan peserta didik, membantu membentuk kepribadian peserta didik, dan sebagai sarana mengembangkan keterampilan peserta didik.

Dari beberapa contoh buku pengayaan, terdapat beberapa kelemahan yang ditemukan. Oleh karena itu, perlu dikembangkan buku pengayaan keterampilan menulis permulaan dengan memperhatikan: (1) proses pemerolehan materi menulis permulaan; (2) perkembangan keterampilan motorik halus peserta didik; dan (3) nilai-nilai karakter. Proses pemerolehan materi menulis permulaan pada buku pengayaan ini diperoleh melalui analisis kebutuhan peserta didik dan guru. Pengembangan keterampilan motorik halus anak juga diperhatikan melalui tahapan menulis permulaan dengan benar, yaitu peserta didik mulai dari membuat garis hingga akhirnya menulis kalimat sederhana berdasarkan gambar. Hal ini dikarenakan materi yang berkaitan dengan menulis permulaan untuk peserta didik kelas I sekolah dasar, yaitu : menebalkan berbagai bentuk garis, huruf, kata, atau kalimat sederhana berdasarkan gambar. Selain itu, buku pengayaan bahasa Indonesia keterampilan menulis permulaan yang bermuatan nilai karakter untuk peserta didik kelas I sekolah dasar, memiliki peran membantu guru membelajarakan keterampilan menulis permulaan pada peserta didik, dan bagi peserta didik dapat menggunakan buku pengayaan sebagai pendamping buku utama pembelajaran materi menulis permulaan.

Menulis permulaan merupakan keterampilan menulis yang memiliki tujuan menulis tingkat pemula yaitu menyalin satuan-satuan bahasa yang sederhana, menulis satuan yang sederhana, menulis pernyataan dan pertanyaan yang sederhana, dan menulis paragraf pendek (Iskandarwassid dan Sunendar 2008:292). Keterampilan menulis seseorang tidak bisa diperoleh secara tiba-tiba. Untuk melakukan kegiatan menulis diperlukan kepiawaian. Menulis merupakan salah satu keterampilan berbahasa yang dipergunakan dalam komunikasi secara tidak langsung dan membutuhkan proses kematangan belajar dan berlatih (Subyantoro 2009:223, Seefeldt \& Barbour 1994:39, Aisyah 2008).

Tidak hanya itu, mulai belajar menulis permulaan juga berkaitan dengan perkembangan motorik halus, peserta didik dapat dilatih keterampilan menulisnya melalui berbagai aktivitas menunjang, antara lain: mencoret-coret di kertas, yang akan berkembang menjadi coretan benang kusut, kemudian menjadi garis lurus, lengkung, dan seterusnya (Hilda 2005, Sujiono 2007).
Terdapat tiga jenis buku pengayaan, yakni: buku pengayaan kepribadian, buku pengayaan keterampilan, dan buku pengayaan pengetahuan (Suherli 2008). Buku pengayaan kepribadian adalah buku yang berisi materi yang dapat membantu membentuk kepribadian seseorang. Buku pengayaan keterampilan adalah buku yang menyajikan materi pembelajaran dengan tujuan meningkatkan penguasaan keterampilan dalam bidang tertentu. Buku pengayaan pengetahuan adalah buku yang memuat materi untuk menambah pengetahuan, wawasan, dan pengalaman pembacanya.

Buku pengayaan yang dikembangkan di dalam penelitian ini adalah buku pengayaan keterampilan. Buku pengayaan keterampilan merupakan buku pengayaan yang memuat materi yang dapat memperkaya penguasaan keterampilan bidang tertentu. Dalam hal ini, buku pengayaan yang dikembangkan adalah buku pengayaan keterampilan menulis permulaan. Menulis permulaan merupakan suatu keterampilan karena dalam kegiatan menulis, peserta didik dituntut untuk menulis dengan kaidah penulisan yang benar. Buku keterampilan menulis permulaan berisi contoh-contoh dan latihan tentang kegiatan menulis permulaan.

Produk pengembangan dalam penelitian ini adalah buku pengayaan untuk mendampingi buku utama dalam pembelajaran bahasa Indonesia. Spesifikasi produk buku pengayaan yang dikembangkan dalam karya pengembangan ini berupa buku pengayaan keterampilan menulis permulaan yang bermuatan nilai karakter pada peserta didik kelas I sekolah dasar. Buku pengayaan yang dikembangkan di dalam penelitian ini terdiri atas buku panduan penulisan buku pengayaan dan buku pengayaan keterampilan menulis permulaan yang bermuatan nilai karakter untuk peserta didik kelas I sekolah dasar.

Peneliti berpijak pada langkah-langkah pengembangan yang dipaparkan dalam buku Sugiyono (2011). Selain itu, kriteria pengembangan buku pengayaan keterampilan menulis permulaan untuk kelas I sekolah dasar peneliti juga berpijak pada pedoman penulisan buku yang dikeluarkan oleh Pusbuk Depdiknas. Dan pemilihan materi menulis permulaan sebagai permasalahan yang diangkat untuk dikembangkan dalam buku pengayaan didasari oleh para ahli dibidang pendidikan anak usia dini tentang belajar menulis anak usia (0-8 tahun). Buku pengayaan keterampilan menulis permulaan yang akan dikembangkan memiliki keterbatasan yaitu pada hal belajar menulis tahap awal yaitu pembuatan coretan bermakna hingga menjadi sebuah kalimat dengan 2-3 kata saja, bukan menulis lanjutan seperti menulis paragraf, wacana, dll.

Penelitian tentang pengembangan buku dan keterampilan menulis permulaan yang pernah dilakukan bahwa kemampuan anak sebelum seorang anak menulis sebuah kata dapat menunjukkan sebuah coretan yang tersusun rapi prosesnya sama halnya dengan kegiatan menulis seorang penulis profesional. Dengan demikian, pentingnya proses belajar menulis bagi anak perlu diperhatikan sejak dini melalui pembelajaran menulis tahap pemula, karena kemampuan menulis seorang anak jika sudah terasah sejak pendidikan dasar akan memberikan pengaruh terhadap pembelajaran lainnya di tahap berikutnya hingga bisa menjadi 
seorang penulis tahap mahir (Harste dkk 1984, Stellakis \& Kondyli 2004).

Pembuktian pengetahuan tentang huruf dalam kemampuan menulis anak prasekolah dan taman kanak-kanak berkaitan dengan penilaian terhadap hasil tulisan dan kemampuan mengidentifikasi huruf. Hasil akhir yang ditemukan, anak usia prasekolah dan taman kanak-kanak lebih dominan menuliskan nama sebagai kegiatan menulis yang mungkin tidak memberikan keuntungan bagi anak dalam perkembangan pengetahuan pengenalan huruf di usia muda dalam pendidikan rendah. Dengan demikian, pentingnya pembelajaran menulis permulaan di sekolah dasar membantu peserta didik yang masih mengalami kesulitan dalam menulis dengan penulisan yang benar di usia prasekolah atau taman kanak-kanak. Keterampilan menulis merupakan salah satu dasar dari berbagai pembelajaran yang akan didapatkan oleh peserta didik karena hampir semua kegiatan pembelajaran dalam bidang pelajaran apapun melakukan kegiatan menulis (Molfese dkk 2011).

Penggunaan metode yang tepat dalam pembelajaran dalam membantu siswa untuk lebih mudah memahami apa yang telah diajarkan. Pentingnya pembelajaran menulis permulaan di usia awal sekolah dengan memperhatikan halhal yang ada di sekitar anak karena anak akan lebih mudah menerimanya. Bagaimanapun, kata dan kalimat merupakan dasar keterampilan menulis. Untuk itu, belajar menulis dengan disesuaikan lingkungan anak akan lebih menyenangkan dan pentingnya mengetahui prosedur penulisan bagi anak sebelum belajar menulis dengan berbagai jenis untuk membantu anak lebih cepat belajar mengenal huruf dan menuliskannya dengan benar serta beberapa hal yang mempengaruhi hasil tulisan peserta didik, antara lain: posisi duduk, posisi kertas, perspektif penglihatan, proses mnegingat, dan salah satunya cara menggenggam pensil dalam belajar menulis sebaiknya disesuaikan dengan kebutuhan anak. (Irfangi 2005, Fellowers 2008, Thwaite 2006, Lorenz 2009, Temur 2011, Hayes 2011).

Buku pengayaan memiliki lima karakteristik, antara lain: (1) materi yang disajikan dalam buku adalah kenyataan; (2) pengembangan isi buku tidak terikat pada kurikulum; (3) penyajian materi secara inovatif; (4) bentuk dari materi yang disajikan dalam buku disesuaikan dengan materi yang terkait; (5) penyajian dilakukan secara kreatif, bisa disertakan gambar yang berkaitan dengan materi.

Dalam menulis buku, salah satunya buku pengayaan, ada empat aspek yang perlu diperhatikan, yaitu: (1) kelayakan materi/isi buku; (2) kelayakan penyajian materi/isi; (3) kelayakan bahasa dan keterbacaan; dan (4) kelayakan aspek kegrafikaan (Depdiknas 2006:10). Dengan demikian, diharapkan buku pengayaan yang disajikan memenuhi syaratsyarat buku yang baik dan layak digunakan sesuai dengan jenjang pendidikan yang ditetapkan.

Menulis merupakan salah satu keterampilan berbahasa yang dipergunakan dalam komunikasi secara tidak langsung dan membutuhkan proses kematangan belajar dan berlatih. Keterampilan menulis merupakan keterampilan berbahasa produktif dan reseptif serta kegiatan menulis membutuhkan kreativitas dalam memanfaatkan grafologi, kosakata, struktur kalimat, pengembangan paragraf. Selain itu, menulis merupakan kegiatan menemukan atau melukiskan lambanglambang grafik yang melambangkan suatu bahasa yang dipahami oleh seseorang, sehingga orang lain dapat membaca lambang-lambang grafis tersebut kalau mereka memahami bahasa dan gambaran grafik itu (Subyantoro 2009:223-228).

Dalam menulis diperlukan adanya suatu bentuk ekspresi gagasan yang berkesinambungan dan mempunyai urutan logis dengan menggunakan kosakata dan tata bahasa tertentu atau kaidah yang digunakan sehingga dapat menggambarkan atau dapat menyajikan yang diekspresikan secara jelas. Itulah sebabnya keterampilan menulis diperlukan latihan yang terus-menerus dan teratur. Pembelajaran menulis perlu diawali suatu bentuk ekspresi gagasan yang berkesinambungan dan mempunyai urutan yang logis mampu menyusun kalimat yang efektif, artinya harus membentuk kalimat yang mengena sasaran sehingga dapat menyusun kalimat dengan baik.

Level-level dalam kegiatan menulis yaitu level pemula dan mahir. Pada level pemula, terdapat tiga tingkatan, yaitu: (1) pemula-rendah; (2) pemula-sedang; dan (3) pemula tinggi. Level pemula-rendah dimaksudkan untuk peserta didik bisa mengenali beberapa huruf dalam sistem abjad. Level pemula-sedang merupakan kegiatan dimana peserta didik diharapkan dapat menyalin kata-kata yang sudah dikenal dan dapat dihafal di luar kepala. Level pemula-tinggi diharapkan mampu menuliskan dokumen sederhana tentang dirinya dan sekitarnya. Level mahir merupakan level pembelajar dimana seseorang memiliki kemampuan untuk menulis panjang dengan beberapa paragraf untuk topik-topik yang sudah dikenal dengan baik. Pada level pemula-rendah, peserta didik diharapkan dapat mengenali beberapa huruf dalam sistem abjad. Hal itu merupakan titik awal seseorang belajar menulis, dimana seorang anak akan mendapatkan pembelajaran menulis abjad secara formal pada jenjang pendidikan dasar kelas I. Betapa penting tahap awal seseorang belajar megenal abjad yang pastinya sesuai dengan kaidah penulisan abjad yang berlaku dengan baik dan benar (Palmer 1985:71-72, Kaplan 1986:15-24).

Menulis permulaan merupakan kegiatan menulis setiap huruf dengan jelas dan memperhatikan bagaimana huruf tersebut diproduksi dengan benar setiap hurufnya. Tidak jelasnya sebuah tulisan akan mengakibatkan makna yang berbeda, untuk itu kebenaran dan ketepatan penulisan merupakan hal yang perlu diperhatikan. Menulis permulaan adalah tahap awal menulis jenjang pendidikan dasar kelas I dan II untuk melatih peserta didik untuk menulis dengan penulisan yang benar setiap hurufnya.

Kegiatan menulis permulaan, disebut permulaan karena kegiatan menulis yang diajarkan pada peserta didik pada awal sekolah dengan menitikberatkan pada kemampuan menulis tingkat pemula, yaitu kemampuan menulis mekanik, di mana kemampuan menulis tersebut akan menjadi dasar pemerolehan pendidikan di sekolah pada bidang ilmu lainnya. Sebagaimana Keputusan Dirjen Pendidikan Dasar dan Menengah Depdikbud No. 094/C/Kep/I.83 tanggal 7 Juni 1983, dan Penegasan Ukuran Tulisan Tangan No. 0521/C2/U.88 tanggal 27 Juni 1988, 
dalam kegiatan menulis yang dipergunakan di sekolah yaitu menggunakan huruf baku merupakan hal penting yang perlu diperhatikan oleh guru-guru sekolah dasar sebagai jenjang pendidikan pertama peserta didik di sekolah.

Awal penulis menggunakan gambar serta menulis untuk membuat makna karena mereka menulis, sangat penting bahwa guru memahami peran yang menggambarkan bermain di pengembangan keseluruhan keaksaraan, kegiatan menggambar beberapa garis adalah tahap awal seorang anak belajar menulis. Sebelum seorang anak menulis huruf dengan benar, anak bisa dirangsang kemampuan menulisnya dengan menggambar beberapa garis, seperti: bentuk lurus, lingkaran, dan beberapa coretan-coretan mudah. Hal tersebut merupakan langkah awal seorang anak belajar menulis sebagai penulis tahap pemula. (Ray 2013, Murtie 2013:99).

Tujuan menulis permulaan yakni : (1) memupuk dan mengembangkan kemampuan siswa untuk memahami dan melaksanakan cara menulis dengan baik dan benar; (2) melatih dan mengembangkan kemampuan siswa untuk mengenal dan menuliskan huruf-huruf (abjad) sebagai tanda bunyi atau suara; dan (3) melatih dan mengembangkan kemampuan siswa agar terampil mengubah tulisan menjadi suara dan terampil menuliskan bunyi/suara yang didengarnya (Novi dkk 2006:299, Iskandarwassid dan Sunendar 2008:292).

Ada beberapa bentuk latihan menulis permulaan yang dapat dilakukan peserta didik, antara lain: (1) latihan memegang pensil dan duduk dengan sikap dan posisi yang benar, (2) latihan gerakan tangan, (3) latihan mengeblat, (4) latihan menghubung-hubungkan tanda titik yang membentuk tulisan, (5) latihan menatap bentuk tulisan, (6) latihan menyalin baik dari buku pelajaran maupun dari tulisan guru pada papan tulis, (7) latihan menulis halus/indah, (8) latihan dikte/imla, (9) latihan melengkapi tulisan (melengkapi huruf, suku kata, atau kata) yang secara sengaja dihilangkan.

\section{METODE}

Penelitian ini menggunakan pendekatan R\&D (Reseach and Development) dengan langkah penelitian yaitu (1) analisis teoretis dan praktis; (2) analisis kebutuhan peserta didik dam guru; (3) penyususnan prototipe; (4) uji prototipe kepada ahli dan guru; (5) revisi prototipe; (6) uji coba lapangan; dan (7) deskripsi hasil penelitian. Data dalam penelitian ini meliputi data kebutuhan karakteristik buku pengayaan yang peserta didik inginkan dan persepsi guru, data hasil penilaian ahli, dan data uji coba terbatas berupa skor. Sampel penelitian ini adalah sumber belajar pada peserta didik kelas I SD.

Pengambilan data dilakukan melalui teknik tes dan nontes. Teknik tes dilakukan untuk mengatahui kemampuan peserta didik dalam menulis permulaan, dan teknik nontes meliputi angket kebutuhan buku pengayaan keterampilan menulis permulaan berdasarkan minat peserta didik dan persepsi guru, angket uji penialian oleh para ahli, observasi terhadap sumber belajar menulis permulaan yang ada di kelas I SD. Sebelum penelitian, dilakukan pengambilan data angket kebutuhan. Teknik analisis data pada penelitian ini dikelompokkan menjadi tiga kemudian dilakukan analisis data. Tiga kelompok data yang dianalisis yaitu: 1) data hasil analisis kebutuhan didapatkan dari angket peserta didik dan guru, 2) data hasil validasi ahli, 3) data hasil uji keefektifan produk (validitas dan reliabilitas).

\section{HASIL DAN PEMBAHASAN}

Kebutuhan pengembangan buku pengayaan keterampilan menulis permulaan yang bermuatan nilai karakter diperoleh dari angket kebutuhan yang diberikan pada peserta didik kelas I sekolah dasar. Dalam tahap ini, dilakukan identifikasi kebutuhan buku pengayaan yang disesuiakan dengan kecenderungan peserta didik kelas I sekolah dasar. Angket yang diberikan pada peserta didik sejumlah 30 soal. Peserta didik kelas I sekolah dasar mengisi angket dibantu peneliti dan rekan peneliti dengan angket terbimbing. Jawaban yang diberikan oleh peserta didik merupakan gambaran yang akan digunakan peneliti untuk melakukan pengembangan buku pengayaan keterampilan menulis permulaan yang bermuatan nilai karakter. Kebutuhan difokuskan pada kegrafikaan buku pengayaan yang anak kehendaki dan nilai karakter. Hal tersebut dikarenakan adanya penyesuaian antara muatan tingkat kesulitan soal dalam angket dan kemampuan peserta didik kelas I sekolah dasar dalam belajar menulis permulaan.

Peseta didik kelas I sekolah dasar merupakan sumber data penelitian, dan hasil yang diperoleh berdasarkan pengisian angket merupakan kebutuhan data penelitian dalam pengembangan buku pengayaan. Peserta didik tersebut berasal dari $\mathrm{SD} \mathrm{Hj}$. Isriyati, SDN Pekunden Semarang; SDN Sendangmulyo 04 Semarang; dan SDN Jatisari Mijen Semarang.

Kebutuhan peserta didik mengenai kegrafikaan buku merupakan hal yang sangat diperlukan dalam perwujudan pengembangan buku pengayaan ini. Melalui hasil analisis tersebut, dapat diketahui seberapa besar keinginan peserta didik atas buku pengayaan yang akan dikembangkan untuk mendampingi buku utama dalam kegiatan belajar di sekolah. Dengan harapan, buku belajar yang tercipta sesuai dengan keinginan dan kebutuhan peserta didik akan menambah semangat belajar. Kesulitan belajar dapat diatasi dengan adanya buku pengayaan seperti yang diinginkan peserta didik karena melalui rasa suka akan membantu peserta didik lebih mudah memahami materi pelajaran yang sedang didapatnya di kelas.

Buku pengayaan yang dikembangkan adalah buku pengayaan keteramilan menulis permulaan. Sasaran pengguna buku tersebut adalah peserta didik kelas I sekolah dasar. Selain untuk membantu peserta didik kelas I sekolah dasar yang baru belajar menulis, buku pengayaan juga perlu bermuatan nilai-nilai karakter. Melalui belajar menulis, peserta didik kelas I sekolah dasar juga dapat memperoleh pembelajaran karakter. Oleh karena itu, di dalam penelitian ini, perlu menganalisis kebutuhan peserta didik dalam penanaman nilai-nilai karakter yang dibutuhkan. 
Dari standar persentase yang ditentukan peneliti sebanyak 70\%, maka berdasarkan hasil di atas buku pengayaan keterampilan menulis permulaan yang bermuatan nilai karakter komunikatif, berani mengambil risiko, bersahabat, peduli sosial, peduli lingkungan, rasa ingin tahu, religius, cinta tanah air tanggung jawab, disiplin, kreativitas, dan gemar membaca.

\begin{tabular}{|c|c|c|}
\hline Subaspek & Prinsip & Kaidah \\
\hline \multirow[t]{8}{*}{$\begin{array}{l}\text { 1. Bagian } \\
\text { Pendah } \\
\text { ulu } \\
\text { Buku }\end{array}$} & \multirow{3}{*}{$\begin{array}{l}\text { Halaman } \\
\text { judul } \\
\text { disajikan } \\
\text { dengan } \\
\text { menarik dan } \\
\text { mudah } \\
\text { terbaca. }\end{array}$} & $\begin{array}{l}\text { Judul buku menggunakan } \\
\text { kalimat penyemangat } \\
\text { belajar anak dan ditulis } \\
\text { dengan bahasa yang baik. }\end{array}$ \\
\hline & & $\begin{array}{l}\text { Nama penulis ditulis jelas } \\
\text { transparan apa adanya tidak } \\
\text { menggunakan inisial. }\end{array}$ \\
\hline & & $\begin{array}{l}\text { Gambar pada halaman } \\
\text { judul disajikan suasana } \\
\text { anak sedang belajar dengan } \\
\text { gembira dilengkapi dengan } \\
\text { perlengkapan belajarnya. } \\
\text { Didukung pula dengan } \\
\text { pemilihan warna-warni } \\
\text { yang cerah sehingga } \\
\text { menarik minat anak. }\end{array}$ \\
\hline & \multirow{2}{*}{$\begin{array}{l}\text { Informasi } \\
\text { umum di } \\
\text { dalam buku } \\
\text { disajikan } \\
\text { dengan } \\
\text { bahasa yang } \\
\text { baik dan } \\
\text { santun. } \\
\end{array}$} & $\begin{array}{l}\text { Isi buku menarik minat } \\
\text { belajar peserta didik dan } \\
\text { mudah dipahami. }\end{array}$ \\
\hline & & $\begin{array}{l}\text { Penyajian informasi umum } \\
\text { berkaitan dengan buku } \\
\text { disampaikan dengan baik } \\
\text { dan jelas. }\end{array}$ \\
\hline & \multirow{2}{*}{$\begin{array}{l}\text { Petunjuk } \\
\text { penggunaan } \\
\text { buku } \\
\text { disajikan } \\
\text { dengan } \\
\text { bahasa yang } \\
\text { baik, teratur, } \\
\text { dan mudah } \\
\text { dimengerti. }\end{array}$} & $\begin{array}{l}\text { Petunjuk disampaikan } \\
\text { secara rinci dan jelas } \\
\text { sehingga mudah dipahami. }\end{array}$ \\
\hline & & $\begin{array}{l}\text { Bahasa yang dipilih untuk } \\
\text { bagian petunjuk } \\
\text { menggunakan bahasa yang } \\
\text { baik, teratur, dan } \\
\text { memudahkan anak. }\end{array}$ \\
\hline & $\begin{array}{l}\text { Daftar isi } \\
\text { disajikan } \\
\text { dengan jelas } \\
\text { sesuai } \\
\text { dengan } \\
\text { urutan isi } \\
\text { buku. }\end{array}$ & $\begin{array}{l}\text { Daftar isi yang mudah } \\
\text { dipahami dapat membantu } \\
\text { pengguna buku untuk } \\
\text { mencari letak halaman yang } \\
\text { diinginkan, untuk itu harus } \\
\text { jelas dan sesuai. }\end{array}$ \\
\hline
\end{tabular}

\begin{tabular}{|c|c|c|}
\hline Subaspek & Prinsip & Kaidah \\
\hline \multirow[t]{2}{*}{$\begin{array}{ll}\text { 2. } & \text { Bagian } \\
& \text { Isi } \\
\text { Buku }\end{array}$} & \multirow{2}{*}{$\begin{array}{l}\text { Buku } \\
\text { pengayaan } \\
\text { keterampila } \\
\text { n berisi } \\
\text { materi }\end{array}$} & $\begin{array}{l}\text { Isi buku lengkap } \\
\text { mengandung aspek uraian } \\
\text { materi menulis permulaan }\end{array}$ \\
\hline & & $\begin{array}{l}\text { Materi yang disajikan } \\
\text { mendukung ketercapaian }\end{array}$ \\
\hline
\end{tabular}

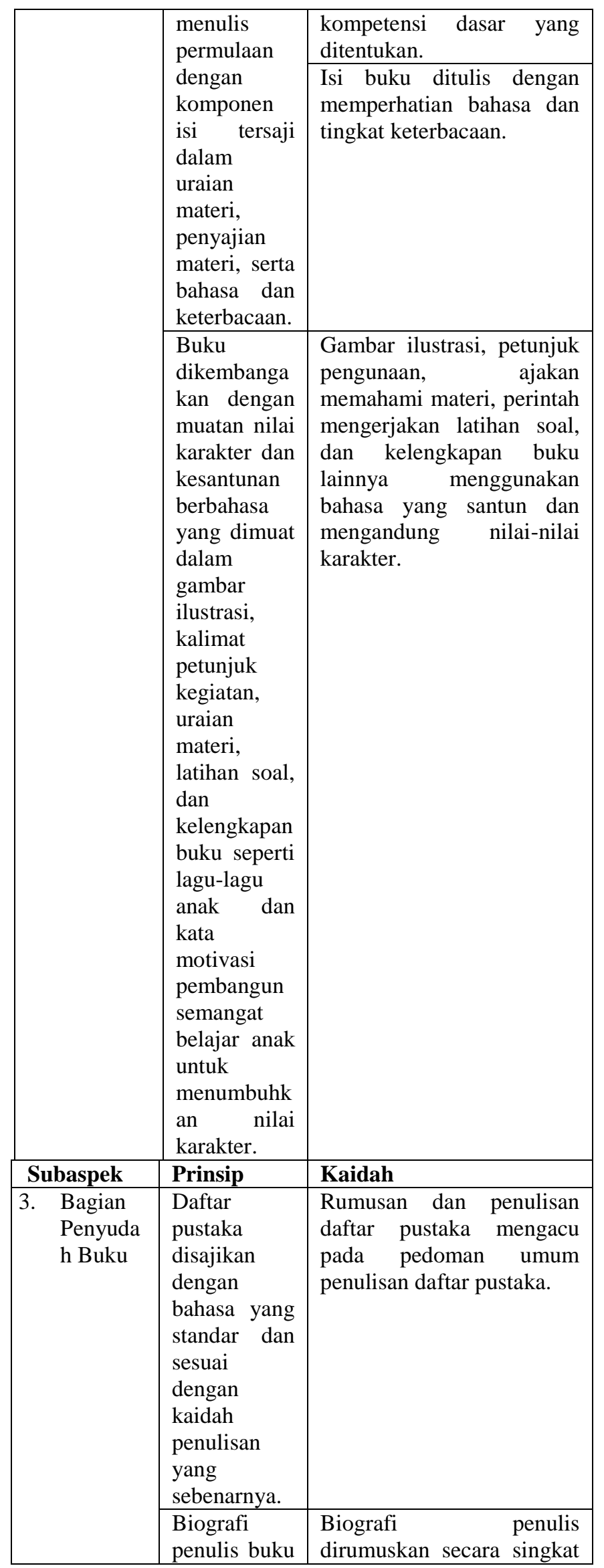




\begin{tabular}{|l|lr|} 
disajikan & dan komunikatif. & \\
\cline { 2 - 3 } menarik & Foto berwarna & penulis \\
pada bagian & berpakaian & sopan \\
akhir & disertakan pada & uraian \\
penyudah & biografi. & \\
buku & & \\
\hline
\end{tabular}

SD Negeri Bugangan 03 merupakan tempat uji coba sample keefektifan buku pengayaan keterampilan menulis permulaan. Cukup diambil satu kelas yaitu kelas I C dengan jumlah peserta didik 30 anak. Uji coba keefektifan dilakukan dengan memberikan tes awal dan tes akhir. Untuk kemudian dibandingkan hasil sudah yang didapatkan. Pengujian keefektifan terhadap produk dilakukan untuk mengetahui kemampuan peserta didik dalam hal menulis permulaan yang bermuatan nilai karakter menggunakan teknik $5 \mathrm{M}$ dan pendekatan saintifik.

Uji keefektifan buku pengayaan keterampilan menulis permulaan yang bermuatan nilai karakter dengan teknik $5 \mathrm{M}$ dihitung menggunakan uji perbedaan rata-rata atau biasa disebut uji $t$ test. Uji tersebut digunakan untuk mengetahui perbedaan nilai rata-rata populasi yang digunakan sebagai pembandingnya yaitu dengan rata-rata sebuah sampel. Uji tersebut dilakukan dengan membandingkan nilai pretest dan postest.

Hasil yang didapatkan yaitu pengujian menggunakan uji dua sisi dengan tingkat signifikansi $\alpha=5 \%$. Berdasarkan uji $t$ test tersebut didapat nilai t hitung 12,306. Adapun tabel distribusi t dicari pada $\alpha=5 \%: 2=2,5 \%$ (uji dua sisi) dengan derajat kebebasan $(\mathrm{dk}) \mathrm{n}-1$ atau $30-1=29$. Dengan pengujian dua sisi (signifikansi 0,025) hasil diperoleh untuk t tabel sebesar 2,045.

Oleh karena $\mathrm{t}$ hitung $>\mathrm{t}$ tabel $(12,306>2,045)$ dan $\mathrm{P}$ value $(0,000<0,05)$ maka Ho ditolak, artinya nilai rata-rata tes awal berbeda dengan nilai rata-rata tes akhir. Hasil t hitung positif menunjukkan bahwa rata-rata nilai tes akhir lebih tinggi dari rata-rata nilai tes awal.

Setelah melakukan uji keefektifan produk, tahap selanjutnya adalah menentukan uji keberterimaan produk yang telah dikembangkan oleh peneliti. Uji keberterimaan ini diperoleh dari penilaian dan pendapat 4 guru kelas I SD Negeri Bugangan 03 yaitu guru kelas I yang sudah lama mendapatkan tugas mengajar di kelas rendah dan tim pengembang kurikulum di SD Negeri Bugangan 03.

Buku pengayaan ini dikembangkan memiliki tujuan untuk membantu peserta didik ketika belajar menulis permulaan supaya menggunakan cara menulis yang benar. Selain belajar menulis, peserta didik juga akan dihadapkan pada materi menulis bermuatan nilai karakter. Penggunaan pendekatan saintifik mengajarkan peserta didik untuk lebih belajar aktif dan dapat menemukan konsep belajarnya sendiri dengan mudah, nyaman, dan benar. Selain itu, nilai-nilai karakter yang disertakan dalam materi menulis permulaan diharapkan dapat diimplementasikan dalam kehidupan peserta didik sehari-hari.

Buku pengayaan keterampilan menulis permulaan dapat memasuki lingkungan pendidikan dengan mudah. Buku "Giat Belajar Membuat Garif, Huruf, dan Kata dengan Benar" merupakan salah satu pedoman yang menyajikan teknik bervariasi dalam belajar menulis tahap awal. Buku tersebut dikembangkan berdasarkan hasil penelitian yang sudah dilakukan, dari berbagai teknik menulis, hanya ada 5 teknik menulis yang membuat peserta didik lebih mudah memahami cara menulis dengan benar. Peneliti melakukan studi teoretis, studi praktis, dan studi lapangan untuk mencari kebutuhan peserta didik. Peneliti tidak memutuskan sendiri, tetapi diberi penilaian dan masukan oleh para ahli dibidangnya, baik dari lingkungan akademisi atau lingkungan publikasi.

Produk dikembangkan sesuai dengan kebutuhan peserta didik pada zamannya, yaitu ketika materi belajar berdasarkan Kurikulum 2013. Untuk itu, di dalam produk yang dibuat, terdapat pendekatan saintifik yaitu suatu pendekatan yang digunakan dalam kegiatan belajar mengajar berbasis Kurikulum 2013.

Buku pengayaan merupakan salah satu sarana untuk mencapai tujuan belajar. Buku pengayaan hanyalah buku pendamping buku utama untuk memenuhi kebutuhan kurikulum karena buku pengayaan tidak terikat dengan kurikulum. Buku pengayaan dikembangkan beriringan dengan kurikulum yang digunakan di Indonesia untuk menyesuaikan langkah belajar yang digunakan buku utama.

Penelitian ini dilaksanakan sebisa mungkin sesuai prosedur. Akan tetapi, tidak bisa dihindari jika ada kekurangan atau keterbatasan yang dilakukan peneliti. Kekurangan dan keterbatasan akan disampaikan peneliti agar tidak terjadi kebingungan dari kemanfaatan hasil buku pengayaan. Keterbatasan yang dimaksud yaitu mencakup: (1) sumber data penelitian, (2) instrumen penelitian, (3) latar pengujian keefektifan produk, dan (4) penyajian materi buku.

\section{SIMPULAN}

Berdasarkan hasil penelitian dan pembahasan yang sudah dipaparkan pada bab IV dapat dikemukakan simpulan sebagai berikut. Pertama, karakteristik kebutuhan buku pengayaan keterampilan menulis permulaan yang bermuatan nilai karakter diperoleh dari empat sekolahan di Kota Semarang, yaitu SD Hj. Isriyati, SDN Pekunden Semarang, SDN Sendangmulyo 04 Semarang, dan SDN Jatisari Mijen. Kebutuhan difokuskan pada kegrafikaan buku pengayaan yang anak kehendaki dan nilai karakter. Hal tersebut dikarenakan adanya penyesuaian antara muatan tingkat kesulitan soal dalam angket dan kemampuan peserta didik kelas I sekolah dasar dalam belajar menulis permulaan.

Kedua, prinsip-prinsip yang telah disusun berdasarkan hasil penelitian akan dijadikan acuan pengembangan produk sebelum buku dicetak dan diujikan kepada para ahli, yaitu meliputi: (1) prinsip pengorganisasian/penyajian buku; (2) prinsip materi buku; (3) prinsip penyajian materi buku; (4) prinsip bahasa dan keterbacaan; dan (5) prinsip kegrafikaan.

Ketiga, prototipe atau draf disusun dengan pembimbingan para ahli dibidangnya baik akademisi maupun publikasi seperti penerbit, hal tersebut dilakukan untuk mengetahui apakah produk sudah layak digunakan untuk sumber belajar. 
Keempat, uji keefektifan dan uji keberterimaan telah dilakukan untuk menilai seberapa efektif buku itu digunakan untuk meningkatkan kemampuan belajar peserta didik tentang menulis permulaan yang berkarakter, dan dapat diterima atau tidak oleh lingkungan pendidikan, terdiri atas 1) uji keefektifan soal isian pretest dan postest, dan 2) uji keberterimaan soal daftar cek.

Peneliti juga mengajukan saran sebagai berikut. Bagi peserta didik, bisa digunakan sebagai salah satu buku pendamping ketika belajar menulis permulaan. Teknik yang disediakan beragam dan sesuai dengan minat peserta didik. Dalam menggunakan buku pastikan dikerjakan secara berurutan karena peneliti sudah mempertimbangkan tingkat kesulitan yang harus dilalui peserta didik, mulai dari teknik termudah hingga tersulit. Selain belajar menulis permulaan, terdapat nilai-nilai karakter yang diajarkan secara tidak langsung melalui materi menulis permulaan yang disajikan. Untuk itu, dihimbau agar peserta didik dapat mengimplementasikan nilai-nilai karakter tersebut dalam kehidupan sehari-hari.

Bagi guru, sebagai fasilitator peserta didik dalam kegiatan belajar, disarankan dapat membantu mengarahkan atau memberikan pembimbingan dengan tahap-tahap yang sudah dituliskan. Semoga buku pengayaan keterampilan menulis permulaan ini dapat menjadi sumber belajar yang bermanfaat untuk tambahan referensi buku pendamping guru dan melengkapi LKS yang selama ini ada di sekolah.

Bagi sekolah, sebagai salah satu tempat belajar formal mengharapkan prestasi yang baik didapatkan oleh peserta didiknya. Buku pengayaan keterampilan menulis permulaan yang bermuatan nilai karakter ini dapat dipergunakan sebagai kebijakan untuk meningkatkan kompetensi peserta didik khususnya dalam keterampilan menulis permulaan dan memperkuat nilai karakter peserta didik.

\section{DAFTAR PUSTAKA}

Fellowes, Janet. (2008). Teaching Writing in the Early Years of School. Jurnal Practically Primary Journal, vol. 13. Australia: Australian Literacy Educators' Association.

Harste, Burke \& Woodward. (1984). When do children start writing? Jurnal Literacy, Families, and Learning, p. 82. London: Cassell.

Hayes, John R. (2011). Kinds of Knowledge-Telling: Modeling Early Writing Development. Journal of Writing Research, 3(2). pp. 73-92. Pittsburgh: Carnegie Mellon University.

Hilda, Karli. (2010). Jurnal Pendidikan Penabur. Vol. 9, No. 15. Membaca dan Menulis untuk Anak Usia Dini melalui Aktivitas dan Permainan yang Menyenangkan. Jakarta: BPK Penabur.

Irfangi, Muhammad. (2005). "Pembelajaran Membaca dan Menulis Permulaan di Kelas I Sekolah Dasar dengan Bermain Kartu Huruf'. Jurnal Surya: Media Informasi Tri Dharma Perguruan Tinggi. Purworejo: Universitas Muhammadiyah Purworejo.
Iskandarwassid dan Dadang Sunendar. (2008). Strategi Pembelajaran Bahasa. Bandung: PT Remaja Rosdakarya.

Kaplan, R. B. (1986). An Introduction to The Study of Written Texts. New York: Newbury House.

Lorenz, Barbara, Tim Green, \& Abbie Brown. (2009). Using Multimedia Graphic Organizer Software in the Prewriting Activities of Primary School Students: What Are the Benefits? Jurnal Computers in the Schools, 26: 115-129.

Molfese, Victoria J., Jennifer L. Beswick, Jill L. JacobiVessels, Natalie E. Armstrong, Brittany L. Culver, Jamie M. White, Melissa C. Ferguson, Kathleen Moritz Rudasill, \& Dennis L. Molfese. (2011). Evidence of Alphabetic Knowledge in Writing: Connections to Letter and Word Identification Skills in Preschool and Kindergarten. Jurnal Springer Science+Business Media B. V. Read Writ 24:133-150. USA: University of Louisville.

Murtie, Afin. (2013). Mengajari Anak Calistung (Membaca, Menulis, Berhitung) Sejak Dini dengan Bermain. Jakarta: PT Gramedia Pustaka Utama.

Palmer, D. (1985). Writing Skills: Practical Techniques in Language Teaching. London: Edward Arnold.

Ray, Katie Wood. (2013). In Pictures and In Words: Teaching the Qualities of Good Writing Through Illustration Study. Portsmouth: Heinemann Publishing.

Ray, Katie Wood \& Matt Glover. (2013). Already Ready: Nurturing Writers in Preschool and Kindergarten. Portsmouth: Heinemann Publishing.

Stellakis, Nektarios \& Marianna Kondyli. (2004). The Emergence of Writing: Children's Writing During The Pre-Alphabetic Spelling Phase. Jurnal Educational Studies in Language and Literature 4: 129-150. Netherlands: Kluwer Academic Publishers.

Subyantoro. (2009). Pelangi Pembelajaran Bahasa. Semarang: Universitas Negeri Semarang Press.

Sugiyono. 2011. Metode Penelitian Pendidikan: Pendekatan Kuantitatif, Kualitatif, dan R\&D. Bandung: Alfabeta.

Suroso. (2007). Panduan Menulis Artikel dan Jurnal. Yogyakarta: Penerbit Elmatera Publishing.

Temur, Turan. (2011). Description of Primary Education 1st Grade Students' Forms of Holding a Pencil as well as Their Grip and Compression Strengths. Jurnal Educational Sciences: Theory \& Practice - 11(4) 21992205. Turkey: Dumlupinar University.

Thwaite, Anne. (2006). Genre Writing in Primary School: From Theory to The Classroom. Australian Journal of Language and Literacy vol. 29, pp 95-114. Australia: Edith Cowan University. 